Original Research Paper

\title{
Menciptakan Usaha Kecil Menengah (UKM) Kekinian Baru Di Desa Janapria
}

\author{
Ghiat Aditiya Ramdani ${ }^{1^{*}}$, Nuriadi ${ }^{2}$ \\ ${ }^{1}$ Program Studi Pendidikan Bahasa Dan Sastra Indonesia, Fakultas Keguruan Dan Ilmu Pendidikan, Universitas \\ Mataram, Mataram, Indonesia \\ ${ }^{2}$ Program Studi Pendidikan Bahasa Inggris, Fakultas Keguruan Dan Ilmu Pendidikan, Universitas Mataram, \\ Mataram, Indonesia
}

DOI: https://doi.org/10.29303/jpmpi.v3i2.557

Sitasi: Ramdani, G. A., \& Nuriadi (2021). Menciptakan Usaha Kecil Menengah (UKM) Kekinian Baru Di Desa Janapria. Jurnal Pengabdian Magister Pendidikan IPA, 4(1)

\section{Article history}

Received: 15 Desember 2020

Revised: 28 Desember 2020

Accepted: 08 Januari 2020

*Corresponding Author: Ghiat Aditiya Ramdani, Program

Studi Pendidikan Bahasa Dan

Sastra Indonesia, Fakultas

Keguruan Dan Ilmu

Pendidikan, Universitas

Mataram, Mataram, Indonesia Email:

Ghiataditiya12@gmail.com

\begin{abstract}
Kuliah Kerja Nyata di era New Normal saat ini memiliki konsep yang berbeda. Ada beberapa macam tema, penulis memilih P1000WB yakni agar dapat menciptakan usaha kecil - kecilan namun masih berkonsep dengan New Normal. Dalam kegiatan berjualan dengan konsep New Normal sesuai dengan Tujuan KKN unram dan daoat pulamengembangkan bakat serta keterampilan mahasiswa. Tema yang dipilih penulis dengan berjualan minuman kekinian saat ini dengan banyak varian rasa dapat menarik perhatian orang - orang banyak. Kegiatan ini dilakukan agar dapat mengenalkan minuman kekinian kepada seluruh warga di desa penulis dan dapat pula menjadi contoh bagi anak anak remaja lainnya untuk mengembangkan kreatifitas mereka. Minuman boba yang berbahan dasar tepung tapioka yang tidak memiliki rasa dengan ditambahnya gula merah dapat menciptakan rasa yang manis sehingga dapat dikonsumsi oleh semua kalangan. tidak hanya dengan rasa melainkan dengan harga dari minuman ini sangat terjangkau.
\end{abstract}

Keywords: KKN New Normal, Minuman Kekinian Boba.

\section{Pendahuluan}

Desa Janapria, Kecamatan Janapria, Kabupaten Lombok Tengah Merupakan salah satu desa yang mengalami keterbelakngan zaman.

Keterbelakangan Desa Janapria serta Sumber Daya manusia (SDM) Ini membuat orangorang dari desa tersebut sedikit lambat mengetahui tentang perkembangan zaman saat ini. Hal itu menimbulkan banyak dari remaja - remaja dari desa tersebut belum banyak mengetahui tentang adanya berbagai macam hal hal baru seperti minuman serta makanan yang kekinian (trending) yang memiliki banyak rasa serta beraneka macam.

Di zaman yang serba maju ini, semakin banyak di temukannya kreativitas orangorang baik dalam hal berjualan dan sebagainya. Contohnya seperti minuman, sekarang terdapat banyak sekali jenis minuman yang dapat di konsumsi, salah satunya adalah boba, boba merupakan suatu benda yang berbentuk bulat, yang memiliki tektur yang kenyal serta rasa yang manis. Boba ini terbuat dari tepung tapioka. Boba mulai terkenal di masyarakat khususnya lombok pada pertengahan tahun 2019 sampai saat ini masyarakat masih sangat menyukai boba.

Alasan penulis mengambil program P1000WB ini karena adanya keterbelakangan perkembangan desa, banyak remaja - remaja yang belum mengetahui berbagai macam minuman kekinian seperti es boba ini. Hal itu lah yang mendasari penulis untuk mengambil program P1000WB. Jika dilihat dari segi peluang usahanya, usaha umtuk menjual produk ini sangatlah cocok karena produk seperti ini belum ada yang menjualnya, dan juga usaha seperti ini bisa 
bertahan hingga satu tahun kedepan dengan melakukan innovasi seperti menambah jenis minuman yang dijual dan tak hanya minuman penulis juga berencana untuk menjual makanan. Usaha boba ini layak diperjual belikan karena harga yang ditawarkan murah, selain itu rasa dari minuman ini sesuai dengan lidah semua kalangan, baik anak-anak, remaja, maupun orang dewasa.

\section{Metode}

\section{Waktu dan tempat}

Program KKN ini dilakukan di dusun Batu Bungus, desa Janapria, kecamatan Janapria, Lombok Tengah, Nusa Tenggara Barat pada bulan November 2020 s/d Januari.

\section{Alat dan Bahan}

Bahan yang digunakan pada program ini adalah yang pertama, boba, susu uht fullcream, gula merah, es batu, dan bubuk varian rasa. Alat yang digunakan pada program ini adalah kompor, panci, sendok, gelas takaran, gelas cup, sedotan, serta peralatan mematuhi prototkol kesehatan pada masa pandemi covid19 ini seperti, masker, dan hand sanitizer.

\section{Bentuk kegiatan}

Bentuk kegiatan dalam program P1000WB ini adalah penciptaan usaha kecil mengengah (UKM) kekinian baru di desa Janapria. 1) Melakukan Survei harga alat dan Bahan minuman, 2) Pembelian alat dan bahan, 3) mempersiapkan alat dan bahan, 4) pembuatan produk 5) melakukan promosi dan penjualan produk.

\section{Metode}

Dalam pelaksanaan KKN Terpadu 2020, penulis menggunakan metode formal untuk mengidentifikasi peluang pasar yang ada. Lalu strategi yang digunakakan dalam mengidentifikasi pasar yakni melakukan reset atau pengumpulan data untuk mengetahui berapa banyak orang yang menyukai minuman boba.

\section{Hasil dan Pembahasan}

Penciptaan UKM kekinian baru merupakan langkah awal yang bagus dalam membangun usaha kecil yang berada di desa Janapria. Memperkenalkan minuman kekinian kepada masyarakat setempat ini bertujuan untuk membangun motivasi masyarakat setempat atau lebih tepatnya remaja setempat agar termotivasi untuk mengembangkan kreatifitas yang mereka miliki dalam membuka usaha baru sehingga dapat mengurangi jumlah pengangguran yang ada di desa, dan juga dapat memunculkan calon pengusaha pengusaha baru.

1. Menciptakan usaha kecil menengah (UKM) kekinian baru di desa janapria. Adapun tahapan kegiatan dari program ini yaitu;

a. Melakukan survei harga alat dan bahan minuman.

Tujuan dari survei ini adalah untuk membandingkan harga, kualitas, kelengkapan bahan maupun alat yang akan digunakan dari toko satu ke toko lainnya.

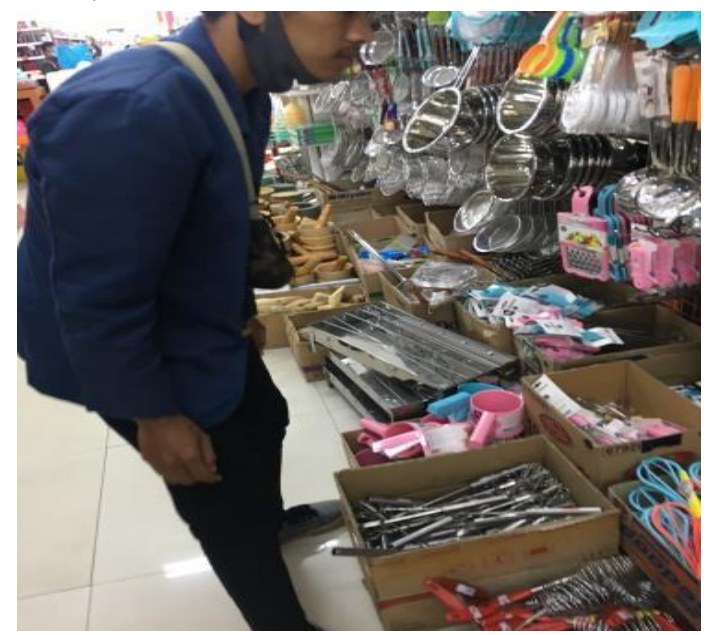

Gambar 1. Melakukan survei harga alat dan bahan.

\section{b. Pembelian alat dan bahan}

Setelah melakukan survei, selanjutnya melakukan pembelian alat dan bahan yang akan digunakan. 


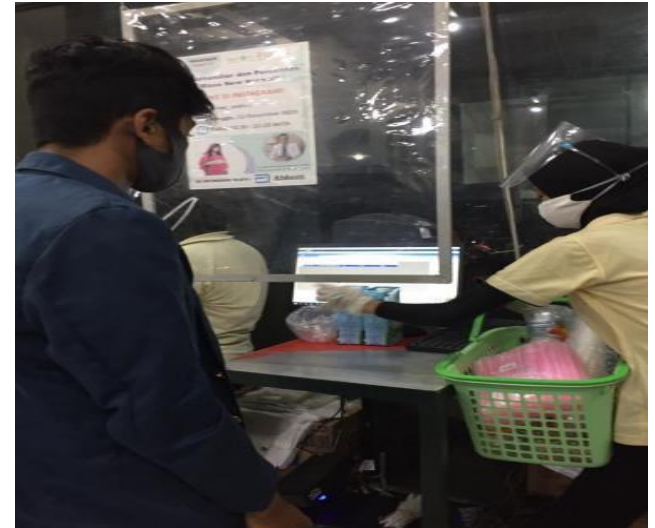

Gambar 2. melakukan pembelian alat dan bahan

c. Mempersiapkan alat

Mempersiapkan alat yakni berupa baliho maupun stiker Lalu setelah baliho jadi tinggal mempersiapkan meja untuk dipasangi baliho dan menemelkan stiker pada gelas untuk branding.

d. Pembuatan produk

Langkah Pertama.

- Pertama masak air sebanyak $300 \mathrm{ml}$

- Lalu setelah mendidih masukan 200 gr boba ke dalam air yang sudah mendidih tadi. Lalu tunggu sampe boba berubah warna menjadi kehitaman, itu menandakan boba tersebut sudah matang.

- Setelah itu masukan 150 gr gula merah parut ke dalam boba yang sudah matang. Lalu Tunggu boba agak dingin, setelah dingin pindahkan boba ke dalam wadah untuk disimpan

Langkah kedua

- Siapkan gelas cup, lalu masukan 1 setengah sdm bubuk varian rasa,

- Lalu seduh dengan air hangat sebanyak $3 \mathrm{sdm}$,

- Masukan boba sebanyak 1 sendok ukuran besar,

- Setelah itu tambahkan es batu secukupnya,

- Lalu tambahkan $100 \mathrm{ml}$ susu UHT fullcream,

- Dan es boba siap disajikan.

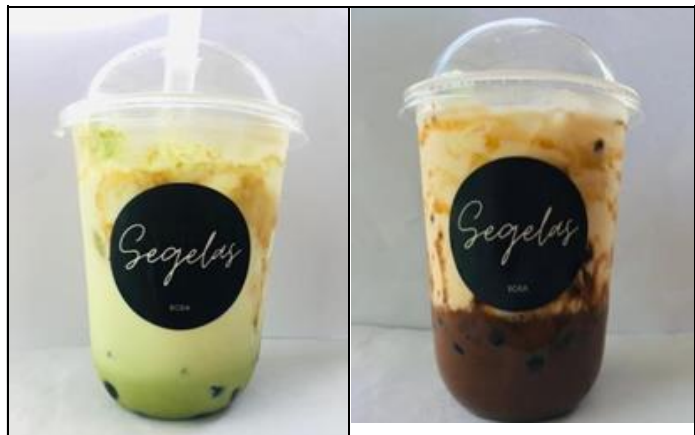

Gambar 3. produk boba yang sudah siap dijual

e. Melakukan promosi dan penjualan produk

- Promosi

Promosi ini dilakukan melalui media sosial berupa whatsapp maupun instagram.

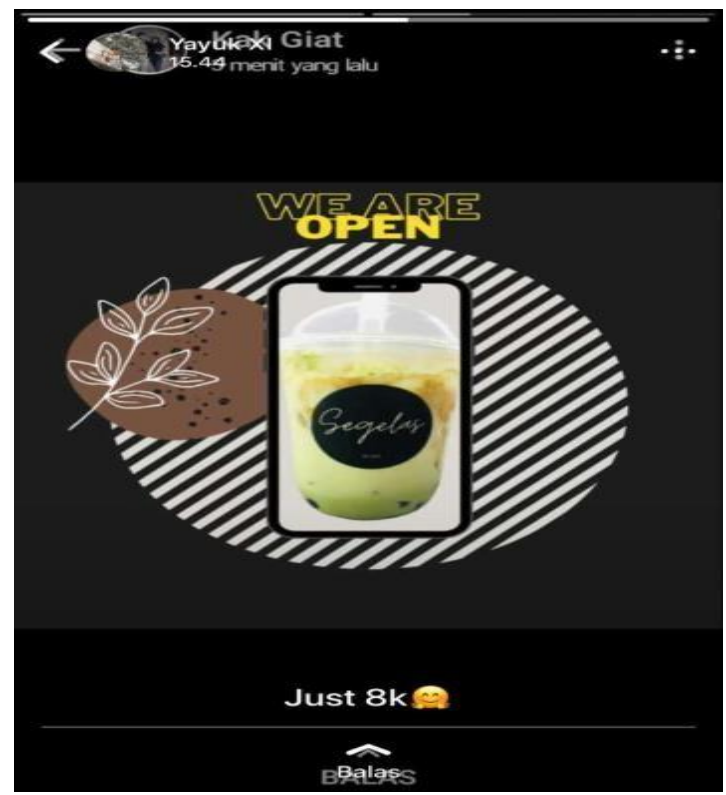

Gambar 4. Melakukan promosi via media sosial.

- Penjualan Produk

Penjualan produk dilakukan di stand segelas boba yang terletak di desa Janapria. 


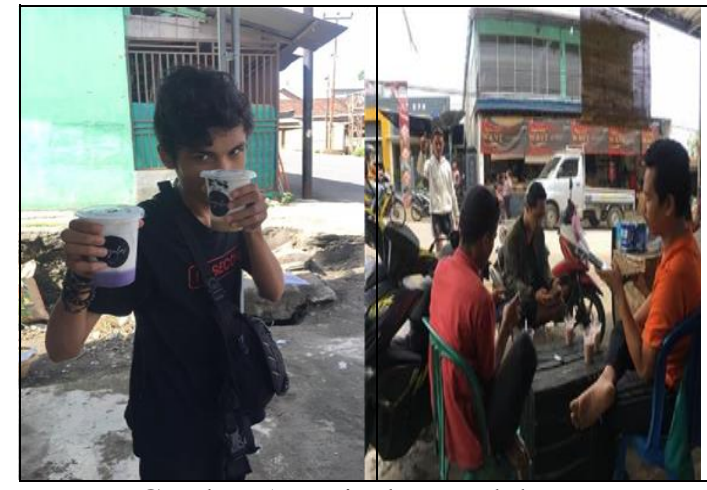

Gambar 5. penjualan produk

\section{Kesimpulan}

Berdasarkan hasil setelah melakukan serangkaian program, program penciptaan usaha kecil menengah (UKM) kekinian baru di desa Janapria. Yakni mulai dari survei harga alat dan bahan, pembelian alat dan bahan persiapan alat, pembuatan produk, hingga promosi dan penjualan produk dilakukan, ternyata masyarakat banyak yang menyukai minuman es boba ini, hal ini terbukti dari hasil penjualan produk ini sudah terjual sebanyak 150 cup dalam jangka waktu 3 minggu.

\section{Ucapan Terima Kasih}

Terimakasih kepada FKIP Universitas Mataram, kemudian saya ucapan terinakasih juga kepada bapak Dr. H. Nuriadi, S. S., M. Hum. Selaku dosen pembimbing lapangan, kemudian saya ucapkan terimakasih kepada mitra KKN saya yakni pengurus desa Janapria, yang sudah menerima saya untuk ber KKN di Desa Janapria, sehingga proses KKN di era New Normal ini bisa di laksanakan.

\section{Daftar Pustaka}

Sutrisno, N. 2003. kewirausahaan dalam pengembangan UKM di Indonesia, makalah disajikan Kongres ISEI ke. Xv.

Krisnamurti, B.2003. Usaha Mikro, kecil dan Menengah: Ekonomi Rakyat Dengan Cara Berekonomi Mereka Sendiri, Makalah disajikan dalam Kongres ISEI ke XV. 